\title{
Comparison of heavy metals levels in muscles, liver and gills of three fish species collected from agricultural drainage water AT EI- Abbassa fish farm, Sharkia, Egypt.
}

\author{
Mohamed Y. M. Aly \\ National Institute of Oceanography and Fisheries, Inland Water and Aquaculture \\ Branch, Al-Kanater Al-Khairya Fish Research Station, Egypt.
}

\section{ABSTRACT}

The concentrations of heavy metals; iron, zinc, copper, lead and cadmium (Fe, $\mathrm{Zn}$, $\mathrm{Cu}, \mathrm{Pb}$, and $\mathrm{Cd}$ ) were determined in water and Nile tilapia, common carp and catfish caught from agricultural drainage water at El- Abbassa fish farm in the period from February to April 2016. Metals concentrations in the water were ranked in the following order $\mathrm{Fe}>\mathrm{Zn}>\mathrm{Cu}>\mathrm{Pb}>\mathrm{Cd}$. The concentrations of $\mathrm{Cu}, \mathrm{Zn}$ and $\mathrm{Cd}$ in water were below the permissible levels according to the Egyptian Standards. Fe and $\mathrm{Pb}$ in the water samples exceeded the permissible limits. The fish muscles, gills and liver were carefully dissected out for digestion and determination of heavy metals. The concentration of heavy metals was analysed in tissues of muscles, gills and liver. The results revealed that $\mathrm{Fe}$ and $\mathrm{Zn}$ concentrations were the highest in all tissues analyzed, followed by $\mathrm{Cu}, \mathrm{Pb}$, and $\mathrm{Cd}$ in almost all three fish species. The highest concentration of Iron $(463.8 \pm 3 . \mu \mathrm{g} / \mathrm{g}$ dry. wt) was detected in the gills of catfish. Whereas the lowest $(255.1 \pm 7.3 \mu \mathrm{g} / \mathrm{g}$ dry. wt) in the muscles of common carp. The highest concentration of $\mathrm{Zn}(203.0 \pm 1 . \mu \mathrm{g} / \mathrm{g}$ dry. wt) was found in the gills of cat fish. While, the lowest $(133.8 \pm 5.0 \mu \mathrm{g} / \mathrm{g}$ dry. $\mathrm{wt})$ was recorded in the muscles of common carp. The highest concentration of copper $(39.2 \pm 3.8 \mu \mathrm{g} / \mathrm{g}$ dry. wt) was detected in the liver of the catfish. While the lowest value $(24.5 \pm 1.2 \mu \mathrm{g} / \mathrm{g}$ dry. $\mathrm{wt})$ in the muscles of the Nile tilapia. For lead and cadmium the highest were found in the liver of catfish (3.7 \pm 0.4 and $2.4 \pm 0.19 \mu \mathrm{g} / \mathrm{g}$ dry. wt), while, the lowest in the muscles of common carp $(1.6 \pm .6$ and $1.1 \pm 0.12 \mu \mathrm{g} / \mathrm{g}$ dry. wt). The results of the present study revealed that the abundance of heavy metals in fish organs followed the order: $\mathrm{Fe}>\mathrm{Zn}>\mathrm{Cu}>\mathrm{Pb}$ and $\mathrm{Cd}$. The concentrations of heavy metals detected in samples of the three fish species, were lower than the recommended maximum level allowed in food by (E.O.S.Q.C.2005), (FAO/WHO1999), (EOS 1993) and (WHO 1989).

Keywords: Heavy metals, nile tilapia, common carp, catfish, muscles, liver, gills.

\section{INTRODUCTION}

Among environmental pollutants, metals are of particular concern, due to its potential toxic effect and ability to bio-accumulate in aquatic ecosystems (Censi et al., 2006).

The pollution of the aquatic environment with heavy metals has become a worldwide problem in recent years, because they are indestructible and most of them have toxic effect on organisms (Mac Farlane and Burchett, 2000).

Heavy metals may have a significant impact on aquatic organisms, disturbing the ecological balance and potentially contaminating the aquatic food chain as well as human (Saeed and Mohamed, 2012). Thus, the concentrations of these compounds are important indicators for contamination level and also can be serious health problem for the population that feeds on them (Mancera et al., 2006). 
Many factors including season, physicochemical properties of water, habitat, age and physiological conditions of fish play a significant role in accumulation of these metals in fish (Kargin, 1996). Gills are directly in contact with water, therefore the concentration of metals in gills reflects metal concentration in water. Presence of high metal concentration in the liver represents storage of metals from water for detoxification (Romeo et al., 1999).

The accumulation of heavy metals within the fish varies depending on route of metal uptake, type of heavy metal and fish species (Begum et al., 2009). The presence of higher amount of heavy metals in any part of the body will induce changes in biochemical metabolisms, serum biochemical changes, histopathological changes and other induced stresses. Therefore the studies on heavy metals accumulation in various organs of the fish are important.

The present study has been conducted to determine iron, zinc, copper, lead and cadmium, concentrations in the gills, muscles and liver of three fish species, Nile tilapia (Oreochromis niloticus), Cat fish (C. gariepinus) and the common carp (Cyprinus Carpio) collected from a fish farm located at Al-Abbassa, Sharkia governorate during February to April 2016.

\section{MATRIALS AND METHODS}

\section{Study area}

The present study was carried out in Al-Abbassa fish farm at Abou Hammad, Sharkia Governorate through February to April 2016.

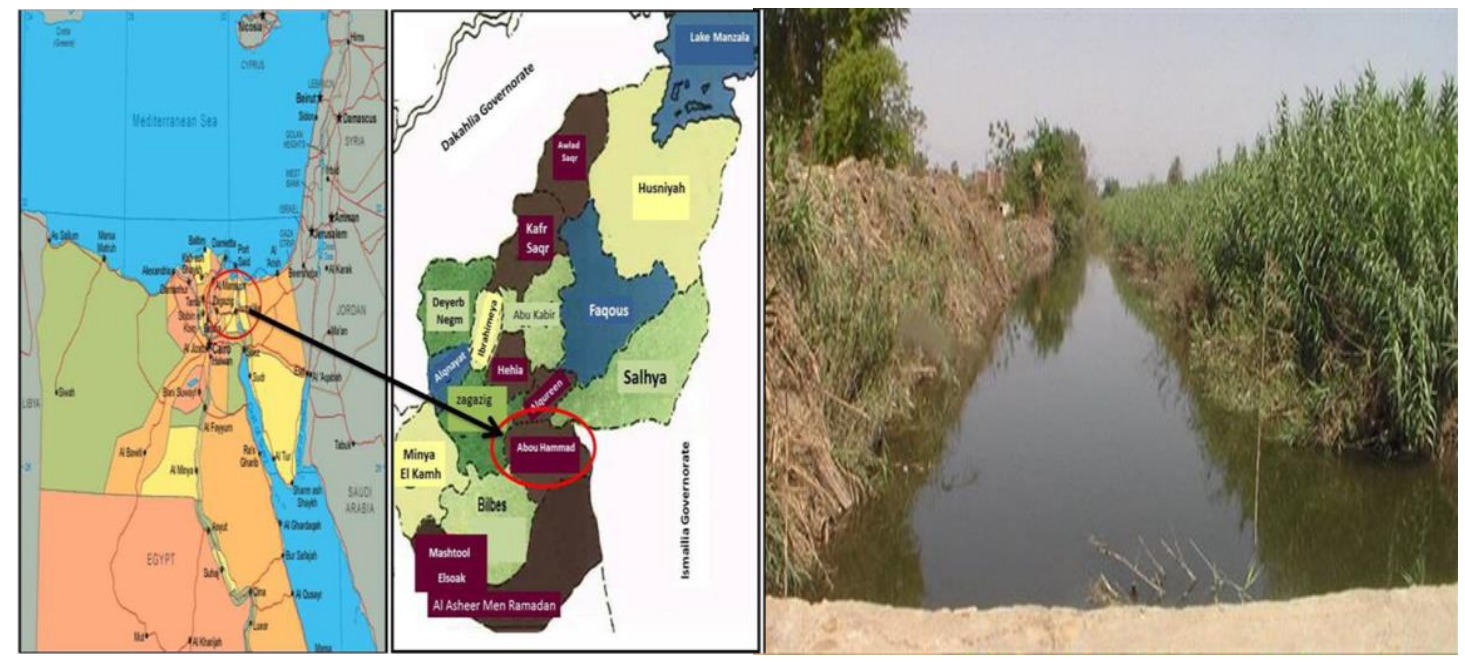

Fig. 1: Map of the Study Area in Egypt.

\section{Fish Sample:}

Three fish species (Seven individuals of each/month) namely the Nile tilapia (Oreochromis niloticus), the cat fish (Claries gariepinus) and common carp (Cyprinus Carpio) were used during this study. They were brought from El-Abbassa agricultural drainage water; close to El-Abbassa Fish farm, during February to April 2016. The tissues from 7 fish individuals per month of the same species were pooled to make 3 sub-samples. 


\section{Analysis of heavy metals: \\ In water:-}

Unfiltered $500 \mathrm{ml}$ water samples were digested according to the procedure reported by APHA (1995). The metals ions of $\mathrm{Fe}, \mathrm{Zn}, \mathrm{Cu}, \mathrm{Pb}$ and $\mathrm{Cd}$ were analyzed by SHIMADZU Atomic Absorption Spectrophotometer Model (AA-6800).

\section{In fish:}

The selected pieces of muscles, gills and liver were dried at $105^{\circ} \mathrm{Cfor} 48$ hours and then grounded to a fine powder. The dried samples were digested according to the method of Ghazaly (1988). One gram dry powder was digested in AR grade conc. nitric and perchloric acid $(5 \mathrm{ml}+5 \mathrm{ml})$. The samples were heated on a hot plat at 800 $900 \mathrm{C}^{\mathrm{O}}$ until they become clear. After cooling the solutions were filtered and the filtrates were adjusted to $50 \mathrm{ml}$ with de-ionized distilled water. The metallic ions were analyzed in water and fish muscle, gills and liver $(\mathrm{Fe}, \mathrm{Zn}, \mathrm{Cu}, \mathrm{Pb}$ and $\mathrm{Cd})$ using SHIMADZU Atomic Absorption Spectrophotometer Model AA-6800 equipped with flame unit and auto-sampler SHIMADZU ASC - 6100. Results were expressed in $\mu \mathrm{g} / \mathrm{g}$ dry weight of the tissue.

\section{Statistical analysis:}

Statistical analysis was performed using the analysis of variance one way (ANOVA) and Duncan's multiple Range Test, to determine differences between means at significance rate of $\mathrm{P}<0.05$. The standard errors of means were also estimated. All statistics were carried out using Statistical Analysis program (SAS, 2000).

\section{RESULTS AND DISCUSSION}

\section{Morphmetric data:}

The biometric characteristics (standard length and weight) of the analyzed fish are listed in Table (1).

Table 1: Mean weights and lengths of examined fish species (mean $\pm \mathrm{SE}$ ).

\begin{tabular}{|c|c|c|c|}
\hline Fish species & Number of fish & Body length $(\mathbf{c m})$ & Body weight $(\mathbf{g})^{\text {O. niloticus }}$ \\
\hline C. carpio & 7 & $17.41 \pm 1.2^{\mathrm{b}}$ & $120.5 \pm 3.05^{\mathrm{c}}$ \\
\hline C.gariepinus & 7 & $31.76 \pm 1.00^{\mathrm{a}}$ & $461.7 \pm 11.53^{\mathrm{a}}$ \\
\hline
\end{tabular}

Data shown with different letters are statistically significant at the $\mathrm{P}<0.05$ level.

\section{Heavy metals concentrations in water:-}

The concentrations of heavy metals in water from the agricultural drainage water are presented in Table (2). Heavy metals were found to be in the following increasing order of concentrations. Fe (345) $>\mathrm{Zn}(157.5)>\mathrm{Cu}(40.95)>\mathrm{Pb}(19.1)>$ $\mathrm{Cd}(3.65)(\mu \mathrm{g} / \mathrm{l})$. The average concentration of $\mathrm{Fe}$ and $\mathrm{Pb}$ in the water samples exceeded the permissible limits prescribed by EOS (1993).

Table 2: The permissible limits, range and (mean $\pm \mathrm{SE}$ ) of concentration of heavy metals $(\mu \mathrm{g} / \mathrm{l})$ in water.

\begin{tabular}{|c|c|c|c|c|c|}
\hline & Fe & Zn & Cu & Pb & Cd \\
\hline Range & $315-375$ & $142-173$ & $38.6-41.7$ & $16.7-21.5$ & $2.6-4.7$ \\
\hline Mean \pm SE & $345.0 \pm 14.5$ & $157.5 \pm 4.9$ & $40.95 \pm 3.4$ & $19.1 \pm 0.6$ & $3.65 . \pm 0.04$ \\
\hline EOS (1993) & 300 & 5000 & 1000 & 10 & 10 \\
\hline
\end{tabular}




\section{Heavy metal concentrations in fish sample:-}

The results of heavy metals concentrations in the organs (liver, gill and muscle) of the three fish species (O. niloticus, $C$. carpio and $C$. gariepinus) are presented in Tables $(3 \& 4)$ and Figs. $(2 \& 3)$. The concentration of heavy metals measured in the organs of the three fish species studied generally lower than the levels issued by E.O.S.Q.C. (2005), FAO/WHO (1999), EOS (1993) and WHO (1989) are presented in Table (5).

Table 3: Concentrations of heavy metals (Mean \pm SE) $(\mu \mathrm{g} / \mathrm{g}$ dry.wt) in different organs of fish species.

\begin{tabular}{|c|c|c|c|c|c|c|}
\hline Fish species & Organ & $\mathbf{F e}$ & $\mathbf{Z n}$ & $\mathbf{C u}$ & $\mathbf{P b}$ & $\mathbf{C d}$ \\
\hline \multirow{3}{*}{ O. niloticus } & Muscle & $299.3 \pm 7.2^{\mathrm{b}}$ & $165.9 \pm 6.4^{\mathrm{a}}$ & $24.5 \pm 1.2^{\mathrm{b}}$ & $1.84 \pm .04^{\mathrm{b}}$ & $1.13 \pm 0.03^{\mathrm{b}}$ \\
\cline { 2 - 7 } & Gills & $332.9 \mathrm{C} \pm 7.8^{\mathrm{a}}$ & $172.5 \pm 9.3^{\mathrm{a}}$ & $31.7 \pm 2.5^{\mathrm{a}}$ & $2.8 \pm .08^{\mathrm{a}}$ & $1.6 \pm 0.07^{\mathrm{a}}$ \\
\cline { 2 - 7 } & Liver & $351.2 \pm 14.8^{\mathrm{a}}$ & $172.3 \pm 9.5^{\mathrm{a}}$ & $28.8 \pm 3.3^{\mathrm{b}}$ & $2.3 \pm 0.3^{\mathrm{a}}$ & $1.4 \pm 0.15^{\mathrm{a}}$ \\
\hline \multirow{3}{*}{ C. carpio } & Muscle & $255.1 \pm 7.3^{\mathrm{c}}$ & $133.8 \pm 5.0^{\mathrm{a}}$ & $28.2 \pm 3.4^{\mathrm{a}}$ & $1.6 \pm 0.6^{\mathrm{b}}$ & $1.1 \pm 0.12^{\mathrm{b}}$ \\
\cline { 2 - 7 } & Gills & $301.3 \pm 8.3^{\mathrm{b}}$ & $144.5 \pm 7.3^{\mathrm{a}}$ & $26.1 \pm 0.9^{\mathrm{a}}$ & $2.6 \pm 0.21^{\mathrm{a}}$ & $1.9 \pm 0.27^{\mathrm{a}}$ \\
\cline { 2 - 7 } & Liver & $336.5 \pm 5.9^{\mathrm{a}}$ & $149.9 \pm 3.5^{\mathrm{a}}$ & $32.6 \pm 1.5^{\mathrm{a}}$ & $2.4 \pm 0.4^{\mathrm{a}}$ & $1.8 \pm 0.38^{\mathrm{a}}$ \\
\hline \multirow{3}{*}{ C.gariepinus } & Muscle & $370.5 \pm 9.5^{\mathrm{b}}$ & $169.3 \pm 1.5^{\mathrm{b}}$ & $27.3 \pm 1.1^{\mathrm{a}}$ & $1.9 \pm 0.1^{\mathrm{b}}$ & $1.4 \pm 0.09^{\mathrm{b}}$ \\
\cline { 2 - 7 } & Gills & $463.8 \pm 3.8^{\mathrm{a}}$ & $203.0 \pm 1.0^{\mathrm{a}}$ & $35.1 \pm 1.3^{\mathrm{a}}$ & $2.5 \pm 0.3^{\mathrm{a}}$ & $1.9 \pm 0.08^{\mathrm{a}}$ \\
\cline { 2 - 7 } & Liver & $393.2 \pm 6.0^{\mathrm{b}}$ & $185.5 \pm 4.1^{\mathrm{b}}$ & $39.2 \pm 3.8^{\mathrm{a}}$ & $3.7 \pm 0.4^{\mathrm{a}}$ & $2.4 \pm 0.19^{\mathrm{a}}$ \\
\hline
\end{tabular}

*All results are expressed as Mean \pm Standard Error (SE) of Mean; $n=21$.

*Data shown with different letters are statistically significant at the $\mathrm{P}<0.05$ level.

Table 4: Mean concentrations of heavy metals (Mean \pm SE) $(\mu \mathrm{g} / \mathrm{g}$ dry.wt) of fish species.

\begin{tabular}{|l|c|c|c|c|c|}
\hline Fish species & $\mathbf{F e}$ & $\mathbf{Z n}$ & $\mathbf{C u}$ & $\mathbf{P b}$ & $\mathbf{C d}$ \\
\hline O. niloticus & $327.8 \pm 9.9^{\mathrm{b}}$ & $171.4 \pm 8.4^{\mathrm{c}}$ & $28.3 \pm 2.3^{\mathrm{b}}$ & $2.3 \pm 0.2^{\mathrm{a}}$ & $1.3 \pm 1.08^{\mathrm{b}}$ \\
\hline C. carpio & $297.6 \pm 7.1^{\mathrm{b}}$ & $142.7 \pm 5.2^{\mathrm{b}}$ & $28.91 .9^{\mathrm{b}}$ & $2.0 \pm 0.7^{\mathrm{a}}$ & $1.5 \pm 0.25^{\mathrm{a}}$ \\
\hline C.gariepinus & $409.2 \pm 6.4^{\mathrm{a}}$ & $185.9 \pm 2.1^{\mathrm{a}}$ & $33.8 \pm 2.1^{\mathrm{a}}$ & $2.7 \pm 0.6^{\mathrm{a}}$ & $1.9 \pm 0.15^{\mathrm{a}}$ \\
\hline
\end{tabular}

*All results are expressed as mean \pm Standard Error (SE) of Mean; $n=21$.

*Data shown with different letters are statistically significant at the $\mathrm{P}<0.05$ level.

Table 5: Maximum Permissible Limit (MPL) of heavy metals in fish (mg/kg wet wt.) according to international standards.

\begin{tabular}{|l|c|c|c|c|c|}
\hline & Fe & Zn & Cu & Pb & Cd \\
\hline E.O.S.Q.C. (2005) & 30 & 40 & 20 & 0.5 & 0.05 \\
\hline FAO/WHO(1999) & 43.0 & 60.0 & 3.0 & 0.214 & 0.1 \\
\hline EOS (1993) & 30 & 40 & 20 & 2.0 & 0.5 \\
\hline WHO (1989) & 50 & 40 & 30 & 0.5 & 0.5 \\
\hline
\end{tabular}

*Permissible limits according to guidelines in E.O.S.Q.C. (2005), FAO/WHO (1999), EOS (1993) and WHO (1989) 

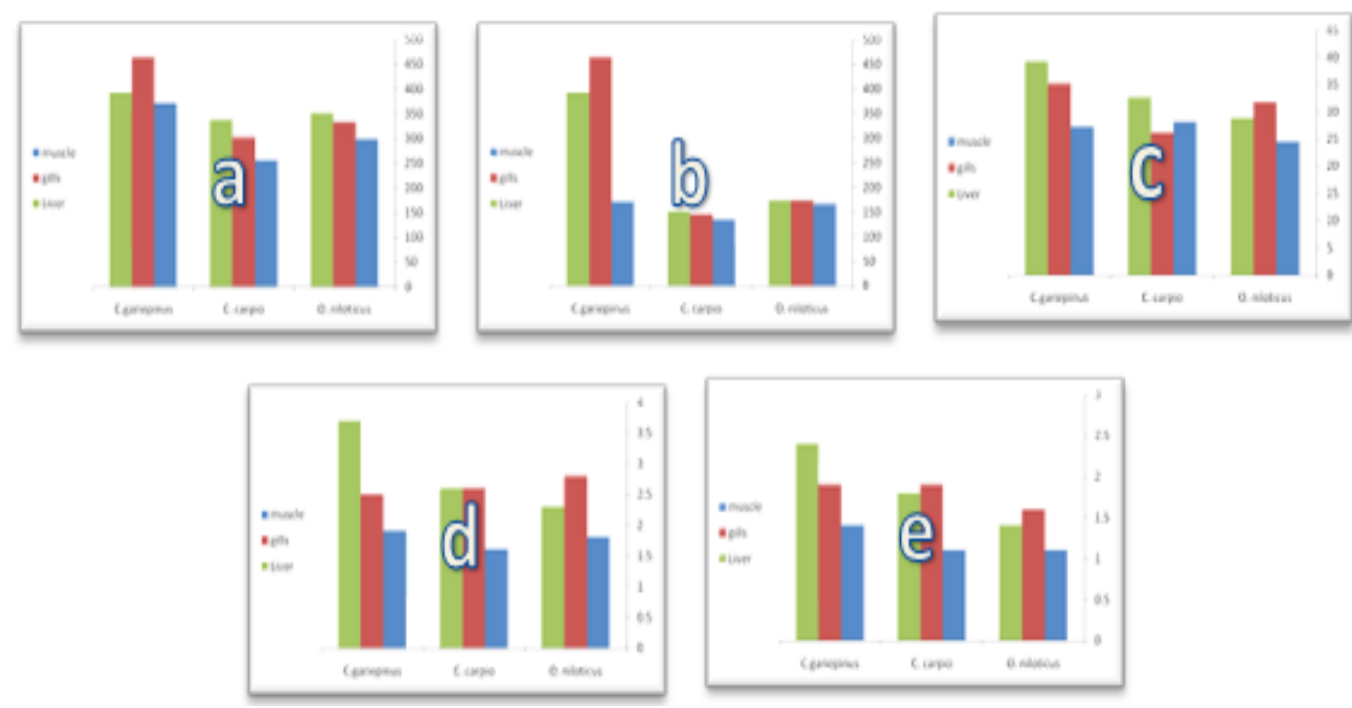

Fig. 2: Variation of heavy metals concentrations in different organs of fish species A: Iron (Fe), B: Zinc $(\mathrm{Zn}), \mathrm{C}$ : Copper $(\mathrm{Cu}), \mathrm{D}$ : Lead $(\mathrm{Pb}), \mathrm{E}$ : Cadiumum $(\mathrm{Cd})$.
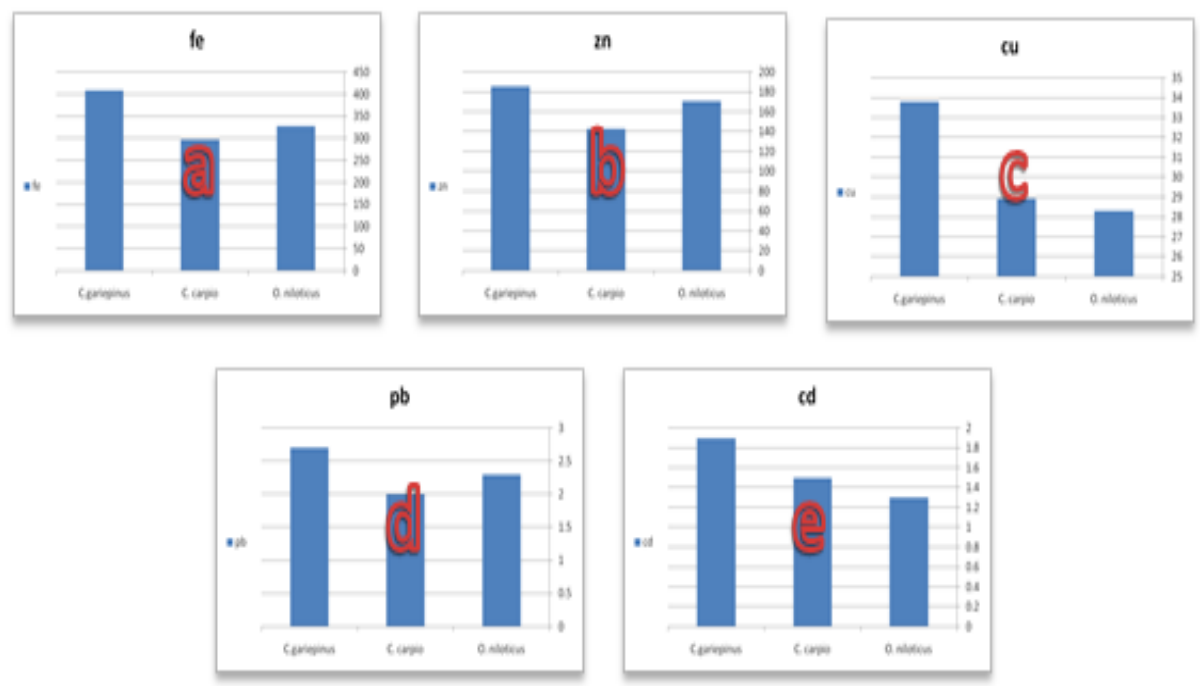

Fig. 3: Variation of heavy metals mean concentrations in different fish species A: Iron (Fe), B: Zinc $(\mathrm{Zn}), \mathrm{C}$ : Copper (Cu), D: Lead (Pb), E: Cadiumum (Cd).

\section{Iron (Fe):}

The concentrations of Fe ranged from $255.1 \pm 7.3 \mu \mathrm{g} / \mathrm{g}$ drywt in muscles of $C$. carpio to $463.8 \pm 3.8 \mu \mathrm{g} / \mathrm{g}$ dry.wt in gills of $C$. gariepinus. It was found that the three fish spices had a significant difference between organs in Fe concentrations $(\mathrm{P}<0.05)$. Its distribution in both $C$. carpio and $O$. niloticu was similar, it was in the increasing order (muscles $<$ gills $<$ liver) with a significant differences among all organs with each other except liver which showed no significant difference in each of the two fish species. In C. gariepinus Fe was in the increasing order (muscles $<$ liver $<$ gills) with a significant differences among all organs in this fish. For Fe level in the three fish species, $C$. gariepinus showed the highest level than $C$. carpio and $O$. niloticu with a significant difference $(\mathrm{P}<0.05)$ among fish spices.

Iron $(\mathrm{Fe})$ concentration in liver and gills were higher than that of muscles. This may be because liver and gills had a high tendency to accumulate high concentrations 
of heavy metals, while muscles tend to retain lower concentrations, these results agree with that recorded by Hamed (1998); Khalil (1997); Singh et al. (1990). Also, it was more than that recorded by El-Ghobashy et al. (2002) and Ali (2007) which ranged between 23.8- 167.3 ppm for muscles, gills and liver and 30.3-194.0ppm in muscles and gills of tilapia spp. Similarly, other studies reported in C. gariepinus (Osman et al. 2010) and Tinca tinca (Selda et al. 2005), also revealed the maximum accumulation of $\mathrm{Fe}$ is in liver. However, in other studies the highest accumulation was seen in organs such as gills in O. niloticus, L. niloticus (Mohamed 2008), $O$. mossambicus (Jenny and Avenant 2006), Liza aurata, Mugil cephalus, and Liza ramada (Uysal et al. 2008).

Zinc (Zn):

The lowest value in muscles of $C$. carpio was $133.8 \pm 5.0 \mu \mathrm{g} / \mathrm{g}$ dry.wt and the highest was in gills of $C$. gariepinus $203.0 \pm 1.0 \mu \mathrm{g} / \mathrm{g}$ dry.wt. For Zn concentration in different organs, $O$. niloticus and $C$. carpio showed no significant difference but $C$. gariepinus had a significant difference $(\mathrm{P}<0.05)$. Its distribution in both $C$. carpio and $O$. niloticu was similar, it was in the increasing order of muscles $<$ gills $<$ liver with no significant differences among all organs of the two fish species. While, it was in the increasing order of muscles < liver < gills in C.gariepinus with a significant differences among organs $C$. gariepinus showed the highest level of $\mathrm{Zn}$ than in $C$. carpio and $O$. niloticu with significant differences $(\mathrm{P}<0.05)$ between fish species.

Highest accumulation of $\mathrm{Zn}$ in liver and gills has also been reported in C.gariepinus (Coetzee et al. 2002). In the present study, it is observed that $\mathrm{Zn}$ content was lower in muscles than liver or gills. Other workers also reported the highest concentration of $\mathrm{Zn}$ in liver of $C$. punctatus (Murugan et al. 2008). However highest accumulation was seen in other organs such as gills of $C$. punctatus (Vineeta et al. 2007), testis of O. niloticus and L. niloticus (Mohamed, 2008). Zinc was detected in all the fish samples and the highest concentrations were observed in gills tissues, followed by liver and muscles. Fish can accumulate zinc from both the surrounding water and from their diet (Eisler, 1993). Although zinc is an essential element, at high concentrations, it can be toxic to fish, causing mortality, growth retardation and reproductive impairment (Sorenson, 1991). Zinc is capable of interacting with other elements and producing antagonistic, additive or synergistic effects (Baumann and May, 1984).

\section{Copper $(\mathbf{C u})$ :}

The lowest $\mathrm{Cu}$ concentration was found in muscles of $O$. niloticus $24.5 \pm 1.2$ $\mu \mathrm{g} / \mathrm{g}$ dry.wt and the highest was found in liver of $C$. gariepinus $39.2 \pm 3.8 \mu \mathrm{g} / \mathrm{g}$ dry.wt. It was found that $C$. gariepinus and $C$. carpio showed no significant difference between organs, but $O$. niloticus had a significant difference $(\mathrm{P}<0.05)$ between organs. Its distribution in both $C$. carpio and $C$. gariepinus was similar; it was in the increasing order of muscles $<$ gills $<$ liver with no significant differences among all organs of the two fish species. In O. niloticus it was in the increasing order of muscles $<$ liver < gills with a significant differences among organs in this fish. It was found that $C$. gariepinus showed the highest level and significant values for $C$. carpio and $O$. niloticus $(\mathrm{P}<0.05)$. This agrees with the findings in other organs such as liver of $O$. nilotica (Abdel- Baki et al. 2011), Onchorynchus mykiss, C. carpio (De Boeck et al. 2004), O. niloticus (Mohamed, 2008) and gills of C. punctatus (Vineeta et al. 2005), Lithognathus mormyrus (Uysal et al. 2008). Muscles accumulated lesser copper than liver and gills, indicating that the food is the primary pathway for uptake of copper. Similar results were observed in different fish species from El Max Bay Alexandria 
(Khaled, 2004).In the present study the lowest concentrations of $\mathrm{Cu}$ were observed in the muscles of studied fish, similar to results recorded by Yacoub (2007).

Lead (Pb):

The concentrations of lead in this study showed it was between the lowest value in muscles of $O$. niloticus $1.84 \pm .04 \mu \mathrm{g} / \mathrm{g}$ dry w.t and the highest value in gills of $C$. gariepinus $3.7 \pm 0.04 \mu \mathrm{g} / \mathrm{g}$ dry w.t.

Lead $(\mathrm{Pb})$ concentration showed no significant $(\mathrm{P}<0.05)$ difference between organs of the three fish species in liver and gills, but the highest from muscles. Its distribution in both $C$. carpio and $O$. niloticus was similar; it was in the increasing order of muscles <liver < gills. While, its distribution in $C$. gariepinus in the increasing order of muscles $<$ gills $<$ liver. In comparison of $\mathrm{Pb}$ level in the three fish species, it was found that $C$. gariepinus showed the highest level than in $C$. carpio and O. niloticu $(\mathrm{P}<0.05)$. Our recorded results were in parallel lines to those reported by many investigators (Hamouda, 1996; Othman et al. 2004; Perziosi et al. 2006). Lead is highly toxics to aquatic organisms, especially fish (Rompala et al. 1984). The biological effects of sublethal concentrations of lead include delayed embryonic development, suppressed reproduction and inhalation of growth, increased mucous formation, neurological problems, enzyme inhalation and kidney disfunction (Rompala et al. 1984).

\section{Cadmium (Cd):}

The concentrations of $\mathrm{Cd}$ in the tissues of fish varied from $1.1 \mu \mathrm{g} / \mathrm{g}$ dry w.t in muscles of $C$. carpio to $2.44 \mu \mathrm{g} / \mathrm{g}$ wet weight in liver of $C$. gariepinus. Cd concentration in different organs showed no significant $(\mathrm{P}<0.05)$ difference between organs of the three fish species in liver and gills but highest significant in muscles. Comparing $\mathrm{Cd}$ levels in the three fish species, it was found that $C$. gariepinus showed the highest level and a significant from $C$. carpio and $O$. niloticu $(\mathrm{P}<0.05)$. In the present study muscles showed no significant $(\mathrm{P}<0.05)$ between the three fish species. These results agree with that recorded by Canli et al. (1998); Khaled (2004); rahman et al. (2012). The results of the present study showed that, liver and gills accumulate and concentrate highest concentrations of Cd. Jent et al. (1998) found that, Cd concentration increased in fish liver collected from water near the agricultural areas. Rashed (2001) found the same results in tilapia fish collected from Lake Nasser. The high accumulation of $\mathrm{Cd}$ in the Kidney corroborated the results obtained by Malik et al. (2010).

\section{CONCLUSION}

The results of the present study revealed that the abundance of heavy metals in fish organs followed the order of $\mathrm{Fe}>\mathrm{Zn}>\mathrm{Cu}>\mathrm{Pb}$ and $\mathrm{Cd}$. The concentrations of heavy metals detected in samples of the three fish species were lower than the recommended maximum level allowed in food by E. O. S. Q. C. (2005), FAO/WHO (1999), EOS (1993) and WHO (1989). The metals content in the livers and gills of fish was considerably higher than that of muscles. A comparison of the species analyzed showed that the $C$. gariepinus accumulates the most of the metals in the liver and gills followed by $O$. niloticus and $C$. carpio. This study indicates that the heavy metals concentrations in muscles of the three fish species are lower than that in gills and liver and within the permissible limits recommended by guideline standards. Therefore these fishes are safe for human consumption. 


\section{REFERENCES}

Abdel- Baki A.S; Dkhil M.A; and Al- Quraishy S. (2011). Bioaccumulation of some heavy metals in tilapia fish relevant to their concentration in water and sediment of Wadi Hanifah, Saudi Arabia. African Journal of Biotechnology, 13(10): 2541- 2547.

APHA (American Public Health Association), (1995). Standard methods for the examination of water and waste water. In A.E. Greenberg, L.S. Clesceri and A.D. Eaton, (Eds.), APHA, WEF and AWWA, 20 ed., Washington DC, USA, 1193 pp.

Ali, M. M. (2007). An analysis of the impact of human activities on water quality and ecological responses in the Suez irrigation Canal. Management of Environmental Quality. An international Journal, 15(3):377-401.

Begum, A; Harikrishna, S. and Khan, I. (2009). Analysis of heavy metals, sediments and fish samples of madivala lakes of Bangalore, Karnataka. Int. J. Chem. Tech. Res., 1(2): 245-249.

Baumann, P.C. and May, T.W. (1984). Nickel residues in fish from inland waters of the United States. In Workshop proceedings, the effects of trace elements on aquatic ecosystems. Electric Power Research Institute, Palo Alto, CA, 7: 1-16.

Canl1, M; Ay, O. and Kalay, M. (1998). Levels of heavy metals (Cd, $\mathrm{Pb}, \mathrm{Cu}, \mathrm{Cr}$ and $\mathrm{Ni}$ ) in tissues of Cyprinus carpio, Barbus capito and Chondrostoma regium from the Seyhan River, Turkey. Turk. J. Zool., 22: 149-157.

Censi, P; Spoto, S. E; Saiano, F; Sprovieri, M; Mazzola, S; Nardone, G; Di Geronimo,S. I;Punturo, R. and Ottonello, D. (2006). Heavy metals in coastal water systems.A case study from the northwestern Gulf of Thailand. Chemosphere, 64: 1167-1176.

Coetzee, L; Du Preez H.H. and Van Vuren J.H.J. (2002). Metal concentrations in Clarias gariepinus and Labeo umbratus from the Olifants and Klein Olifants River, Mpumalanga, South Africa: Zinc, copper, manganese, lead, chromium, nickel, aluminium and iron. Water SA, 28: 221-226.

De Boeck G; Meeus W; De Coen, W. and Blust R. (2004). Tissue specific Cu bioaccumulation patterns and differences in sensitivity to water borne $\mathrm{Cu}$ in three fresh water fish: rainbow trout (Oncorhyncus mykiss), common carp (Cyprinus carpio), and gibel carp (Carassius auratus gibelio). Aquatic Toxicology, 70: 179- $188 \mathrm{pp}$.

Eisler, R. (1993). Zinc hazards to fish, wildlife and invertebrates: a synoptic review. U.S. Fish Wildl. Serv. Biol. Rep; 85(1.10). 90

EOS. (1993). Egyptian standard, maximum levels for heavy metal concentrations in food., 546-815 pp.

E.O.S.Q.C. (Egyptian Organization for Standardization and Quality Control), (2005). The permissible limits for fish., 1-889 / 2005.

El-Ghobashy, H. A; Zoghloul, K. H. and Metwally, A. A. (2002). Effect of some water pollutants on the Nile Tilapia (Oreochromis niloticus) collected from the River Nile and some Egyptian lakes, Egypt. J. Aquat. Biol. \& Fish, 5(4): 251279.

FAO/WHO, Expert Committee on Food Additives. (1999). Summary and conclusion, $53{ }^{\text {rd }}$ meeting, Rome, 1-10 June.

Ghazaly, K. S. (1988). The bio-accumulation of potential heavy metals in tissues of Egyptian edible marine animals. Part: Crustacean. Bulletin of National Institute of . Oceano-graphy \& Fisheries ARE., 14 (2): 71-77. 
Hamed, M.A. (1998). Distribution of trace metals in the River Nile ecosystem, Damietta branch between Mansoura city and Damietta Province. J/ Egypt., Ger. Soc. Zool., Comparative Physiology, 27(A): 399-415.

Hamouda, E.E. (1996). Pathological studies on fish xperimentally intoxicated by certain heavy metals. PH-D Thesis, Dept. Pathol. \& Parasitol, Fac. Vet. Med., Alex. Univ.

Jenny Robinson and Avenant- Oldewage A, (2006). Chromium, Copper, Iron and Manganese bioaccumulation in some organs and tissues of Oreochromis mossambicus from the lower Olifants River, inside the Kruger National Park water S A, 23(4): pp. 387.

Khaled, A. (2004). Heavy metals concentrations in certain tissues of five commercially important fishes from El Max Bay, Alexandria, Egypt. Egypt. J. Aquatic Biol. \& Fish, 8(1): 51- 64.

Kargin, F. (1996). Seasonal changes in levels of heavy metals in tissues of Mullus barbatus and Sparus aurata collected from Iskenderum Gulf (Turkey). Water Air Soil Poll., 90: 557-562.

Khalil, M. T. (1997). Changes in the mullet fishery of Lake Manzala, Egypt. Intern. J. Salt Lake Res., 5: 241-251.

MacFarlane, G. B. and Burchettt, M. D. (2000), cellular distribution of $\mathrm{Cu}, \mathrm{Pb}$, and $\mathrm{Zn}$ in the Grey Mangrove Avicemnia marina (Forsk.). Vierh Aquatic Botanic, 68: $45-59$.

Mancera, R; Alvarez, N. J. and Leomo, R. (2006). Current state of knowledge of the concentration of mercury and other heavy metals in freshwater fish in Colombia, Acta-Biologica-Colombiana, 11 (1): 3-23.

Mohammad, F. A. (2008). Bioaccumulation of selected metals and histopathological alterations in tissues of Oreochromis niloticus and Lates niloticus from lake Nasser, Egypt. Global Veterinaria, 4(2): 205- 218 pp.

Othman, A.I.; Sharawy, S.A. and EL-Missiry, M.A. (2004). Role of melatonin in a meliorating lead induced haematotoxicity Pharmacological Res., 50: 301-307.

Petkovsek, S.A.S; Grudnik, Z.M. and Pokorny, B. (2012). heavy metals and arsenic concentration in ten fish species from the Šalek lakes (Slovenia): assessment of potential human health risk due to fish consumption. Environmental Monitoring and Assessment, 184: 2647-2662.

Perziosi, S; Gridelli, P; Borghetti, A; Walsh, M. and Berzins, I. (2006). Spinal deformity in a sand tiger shark, Carcharias Taurus Rafinesque; a clinical pathological study. J. Fish Dis, 29(1): 49-60.

Rahman, M.S; Molla, A.H; Saha, N. and Rahman, A. (2012). Study on heavy metals levels and its risk assessment in some edible fishes from Bangshi River, Dhaka, Bangladesh. Food Chem, 134:1847-1854; 76:181-188.

Rashed, M.N. (2001). Monitoring of environmental heavy metals in fishfrom Nasser Lake. Environ. Int, 27: 27-33.

Rejomon, G; Nair M. and Joseph, T. (2010). Trace metal dynamics in fishes from the southwest coast of India. Environmental Monitoring and Assessment. Doi; 10.1007-s 10661- 009- 1046-y.

Romeo, M; Siau, Y; Sidoumou, Z. and Gnassi-Barelli, M. (1999). Heavy metal distribution in different fish species from Manritania Coast. Sci. Total Environ; 232: $169-175$.

Rompala, J.M; Rutosky, F.W. and Putnam, D.J. (1984). Concentrations of environmental contaminants from selected waters in Pennsylvania. U.S. Fish Wildl. Serv. Rep; State College, Pennsylvania., 102. 
Saeed, S. M. and Mohamed, M.A. (2012). Influence of physico-chemical characteristics of water on metals accumulation in water and Tilapia zillii inhabiting different habitats in Egypt. Journal of the Arabia Aquaculture Society, 7 (1): 29-50.

Selda, O; zana, E. And Ismail, K. (2005). Comparative study on the accumulation of heavy metals in different organs of tench (Tinca tinca L.1758) and plerocercoids of its endoparasite Ligula intestinalis. Parasitol Research, 97: 156-159.

Singh, N.K; Varma, M.C. and Datta, J.S. (1990). Accumulation of copper, zinc, lead, iron, and cadmium in certain freshwater fishes of River Subernaretah. J. Fresh. Wat. Biol., 2(3): 189-193.

Sorenson, E.M. (1991). metal Poisoning in Fish. CRC Press, Inc. Boca Raton, Florida, 119-174.

Uysal , K; Yilmaz, E. and Koca E. (2008). The determination of heavy metal accumulation ratios in muscles, skin and gills of some migratory fish species by inductively coupled plasma- optical emission spectrometry (ICP- OES) in Beymelek Lagoon (Antalya/ Turkey), Microchemical Journal, 90: 67-70 pp.

Vineeta, S; Monika, D; Prakash, J. and Sastry, K. V. (2007). Bioaccumulation of Zn, $\mathrm{Cu}$ and $\mathrm{Cd}$ in Channa punctatus. Journal of Environmental Biology, 2(28); 395$397 \mathrm{pp}$.

WHO, World Health Organization (1989). Heavy metals-environmental aspects; Environment health criteria. No.85. Geneva, Switzerland.

Yacoub, A. M. (2007). Study on some heavy metals accumulated in some organs of three River Nile fishes from Cairo and Kalubia governorates. African J. Biol. Sci., 3(3): 9- 21.

\section{ARABIC SUMMARY}

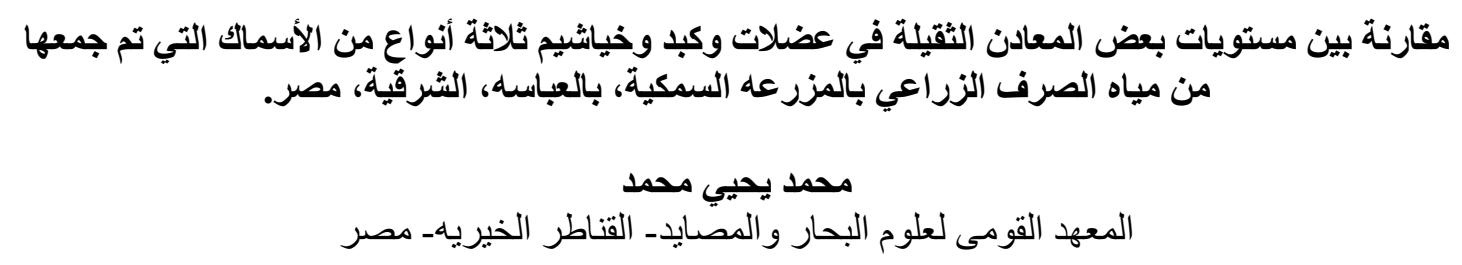

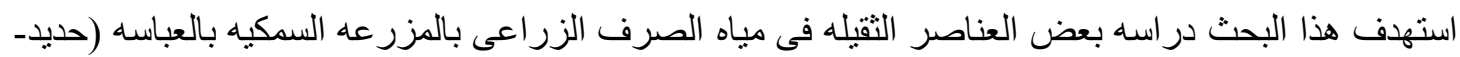

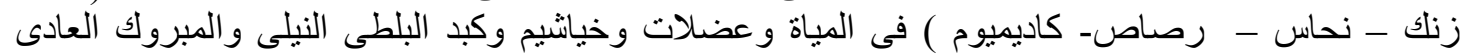

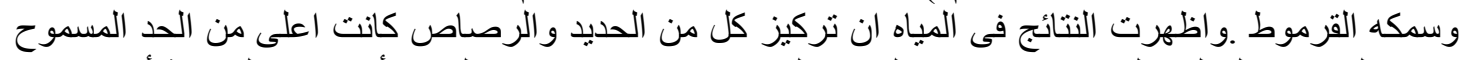

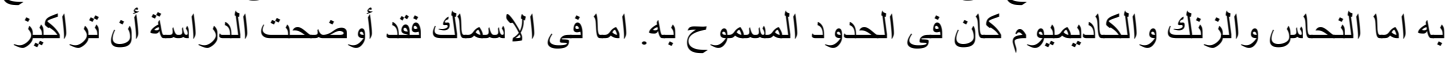

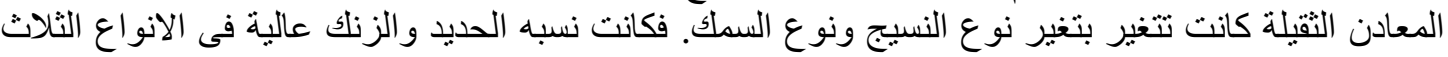

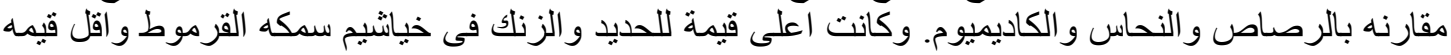

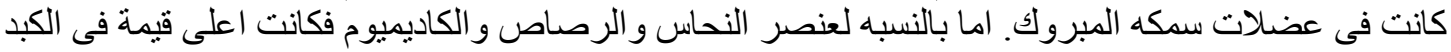

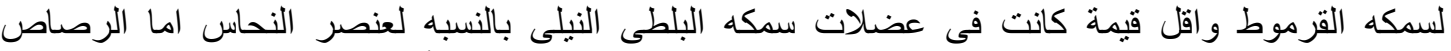

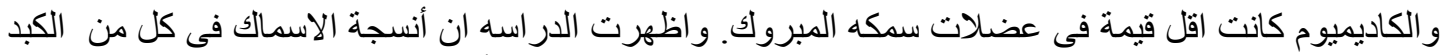

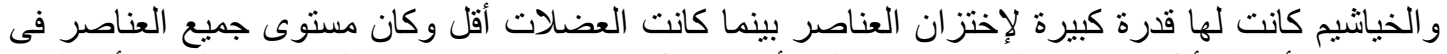

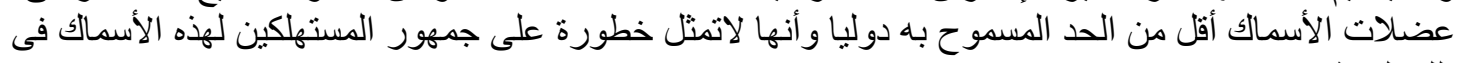

